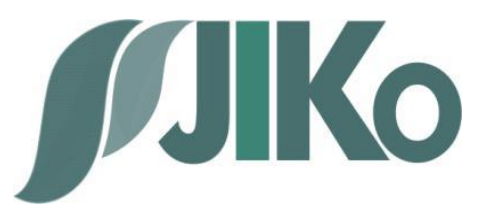

\title{
Tourist perception of the intention to visit green open space
}

Novi Puji Lestari ${ }^{1}$, Yeyen Pratika ${ }^{2}$

Management Department, Universitas Muhammadiyah

Malang, Indonesia ${ }^{1,2}$

Received: 20-01-2020| Revision: 21-01-2020 | Accepted: 18-03-2020

\begin{abstract}
Tourism is one of the industries that is growing very rapidly in global market. This condition is due to the changes in consumer behavior that makes traveling as a lifestyle and necessity. Green Open Space is one of the tourist destinations that can be used as an attraction as well as an important aspect in the concept of Sustainable Development Goals (SDGs). As one of the tourist destination cities in Indonesia, Batu City has the potential to develop green open space as an alternative tourism destination. The existence of social media in the tourism industry also cannot be ignored given the perceptions that encourage the intention to visit certain tourist destinations. Thus, this study aims to examine the extent to which social media perceptions can influence tourists' intentions to visit green open tourist destinations in Batu. The data collection method in this study uses a questionnaire distributed online and will be obtained using Structural Equation Modeling (SEM).
\end{abstract}

Keywords: tourism, green open space, perception, intention

\section{Introduction}

The development of tourism industry has continued to increase in the past few decade. Indonesian Ministry of Tourism mentioned that traveling has been rated as part of lifestyle for most of the world community, including Indonesian. The increasing needs of society in tourism provides potential benefits for many parties in the tourism industry (Hornberger \& Nevill, 2011). In 2018, tourism industry contributed foreign exchange of more than IDR223 trillion and was targeted to be IDR 280 trillion in 2019. This figure is considered very realistic due to the increasing arrivals both local and foreign tourist to Indonesia each year. The results of research conducted by the World Travel \& Tourism Council (WTTC) also revealed that tourism is one of the largest economic sectors in creating employment opportunities and the welfare of world community. WTTC also noted that in 2017, the tourism sector contributed up to 8,272 billion US dollars $(10.4 \%$ of world GDP) and was able to absorb as many as 313 million workers in the world (WTTC, 2018).

In addition, tourist destinations are also increasingly diverse and growing very rapidly. Tourist destinations no longer only refer to natural attractions, such as beaches and mountains. Green Open Space such as parks, botanical gardens and urban forests can also be an attractive alternative tourist destination. (Cianga \& Popescu, 2013) said

\footnotetext{
${ }^{1}$ novipujilestari61@gmail.com

2 yeyenpratika@umm.ac.id
} 
that as a component of urban planning, green spaces do not only have a role as a counterweight to the quality of the environment in cities, but also attractiveness to the population and provides other aspects of the tourism industry such as recreation, culture, tourism business, etc. The concept of green space as an urban tourism destination is in line with United Nation's global planning known as Sustainable Development Goals (SDGs). (Lestari, 2014) revealed that green open space based on environmental, economic and social aspects has a potential to encourage the creation of sustainable cities.

The development of technology especially the use of social media also affects the tourism industry. For tourists, social media can be used as a tool to find information about ticket promotions, accommodation discounts, and the latest destination trends. Meanwhile, social media can also be used as an effective promotion. The World Economic Forum (2015) stated that tourism business activities are strongly influenced by the internet, especially in planning tourist visits, transportation and accommodation bookings. The Boston Consulting Group (2014) also reported that 95\% of tourists use digital information sources to plan their tourist visits.

As one of the largest tourist destination destinations in Indonesia, Batu City is considered to be very active in taking up these opportunities. Various theme parks and other tourist destinations have been opened and developed in recent years. Wahyuni (2016) said that the majority of tourists visited Batu City is to experience city parks. Research conducted by Kusumastuti and Soemardiono (2016) also stated that government keeps continuing the revitalization of green open spaces which has been misused as a commercial building.

Based on Ministerial Regulation number 05/prt/m/2008 concerning the guidelines of providing Green Open Space in urban areas, it is stated that the total green space for an area is at least 30 percent (Ministerial Regulation, 2008). Meanwhile, Batu City, according to the Office of the Environment (DLH), has a program that has been launched and is being carried out, namely creating a thousand parks in Batu City. This program is intended to increase the number of green space that has not reached $30 \%$ and also an effort to increase the existing potential tourism. The Central Bureau of Statistics (2018) stated that there are around 4.2 million tourists visiting Batu City in 2017 with a percentage of $25 \%$ visiting Selecta which is one of the leading green spaces tourism in Batu City (BPS, 2018).

To further increase tourist visits, various things need to continue to be done, one of them is through social media. The presence of perceived social media often influences the image of a tourist destination that can encourage or discourage tourists to visit the destination. As one of the e-WOM (electronic Word-of-Mouth) media, social media is a very important source of information for individuals in determining their tourism destinations (Xiang \& Gretzel, 2010). It is also considered to affect the intention of visiting tourists to green space as an alternative tourism that is different. Xiang \& Gretzel (2010) stated that social media is a very important source of information for tourist in planning their trips due to this media provides individual perception. In addition, eMarketer (2011) found that social media is the place in which most of various types of products are discussed, including tourist destinations.

Several previous studies have examined the factors influence tourist visiting intentions. Chu and Luckanavanich (2018) said that the habit of using social media is an 
important factor that influences individual's intention to visit and decision making process of a trip. However, there is a limited research conducted on green open space tourism related to social media. Thus, this research aims to examine the role of social media perception on the intention to visit green open space. This research is expected to contribute in the tourism, consumer behavior and marketing literatures.

\section{Research Method}

This research is explanatory research that aims to examine the relationship between variables that are the focus of research (Cooper and Schindler, 2014). Data collection in this study uses communication techniques through a self-administered survey using a questionnaire that is distributed online with a cross-sectional time dimension. This research uses primary data types and sources. Primary data is data obtained directly from respondents based on the results of the distribution of questionnaires. This data is chosen to find the closeness between the phenomenon under study and to control the bias that can occur.

The population and unit of analysis used in this study are tourists who know one of the green open space tourism destinations in Batu City. Respondents are asked to fill out a questionnaire that describes their profile and assessment of those tourism destinations. The determination of the sample in this study uses the non-probability method because the population cannot be clearly identified (Cooper and Schindler, 2014: 358). This study uses targeted sampling techniques because the samples are selected based on specific criteria set (Cozby and Bates, 2012: 147).

The characteristics of the sample determined are tourists with a minimum age of 17 years and have visited one of the green open space tourism in Batu City in the last 12 months. The sample size in this study uses the maximum likelihood estimation (MLE) technique. The ideal number of sample sizes using this technique ranges from 100 to 400 respondents. The maximum likelihood estimation technique (MLE) is determined based on several reasons, namely: (1) this technique can provide stable and valid results with a minimum sample size of 50, (2) this technique can minimize the existence of bias when assuming multivariate normality is met (Hair et al., 2014).

This questionnaire consists of 14 statements and distributed to tourists who have visited green open space tourism destination in Batu City. There are 155 respondents involved in this study. This research consists of content validity and construct, the construct of the research model can be seen in Fig. 1. the data is collected, all data is processed using SmartPLS. The construct validity can be provided through the estimation of standardized factor loading in each indicator. Hair et al. (2014) states that the estimated standardized loading must be greater than 0.50 or ideally greater than 0.70 . Reliability is used to measure each indicator or measure the consistency of each indicator. Validity test is applied through the Construct Reliability (CR) analysis. Hair et al. (2014) stated that reliability is stated as good if the value is more than or equal to 0.7 . 


\section{Result and Discussion}

This research results in CR that all variables have values above or equal to 0.7 . The result can be shown on Table 1. Perception is defined as a process that is the awareness of many stimuluses that affect one's sense (DeVito, 2011). The presence of social media has a significant influence in the development of tourism in which it gives a specific perception for individuals towards a tourist destination. Research conducted by Volo (2010) found that social media influences how a tourist destination is perceived by someone. This study found that individual perceptions formed through social media have an influence on the cognitive image and affection of a tourist destination. This results of study are supported by Chu \& Luckanavanich (2018) which stated that the intention of traveling is determined by perceived social media, motivation and destination image. It also stated that social media has different influences on cognitive and affective image of tourist destination. Through reading or seeing social media, individual unconsciously make perceptions related to tourist destinations. PalaciosMarqués, Merigó, \& Soto-Acosta (2015) also conveyed that the presence of social media influences someone's judgement that provides certain image.

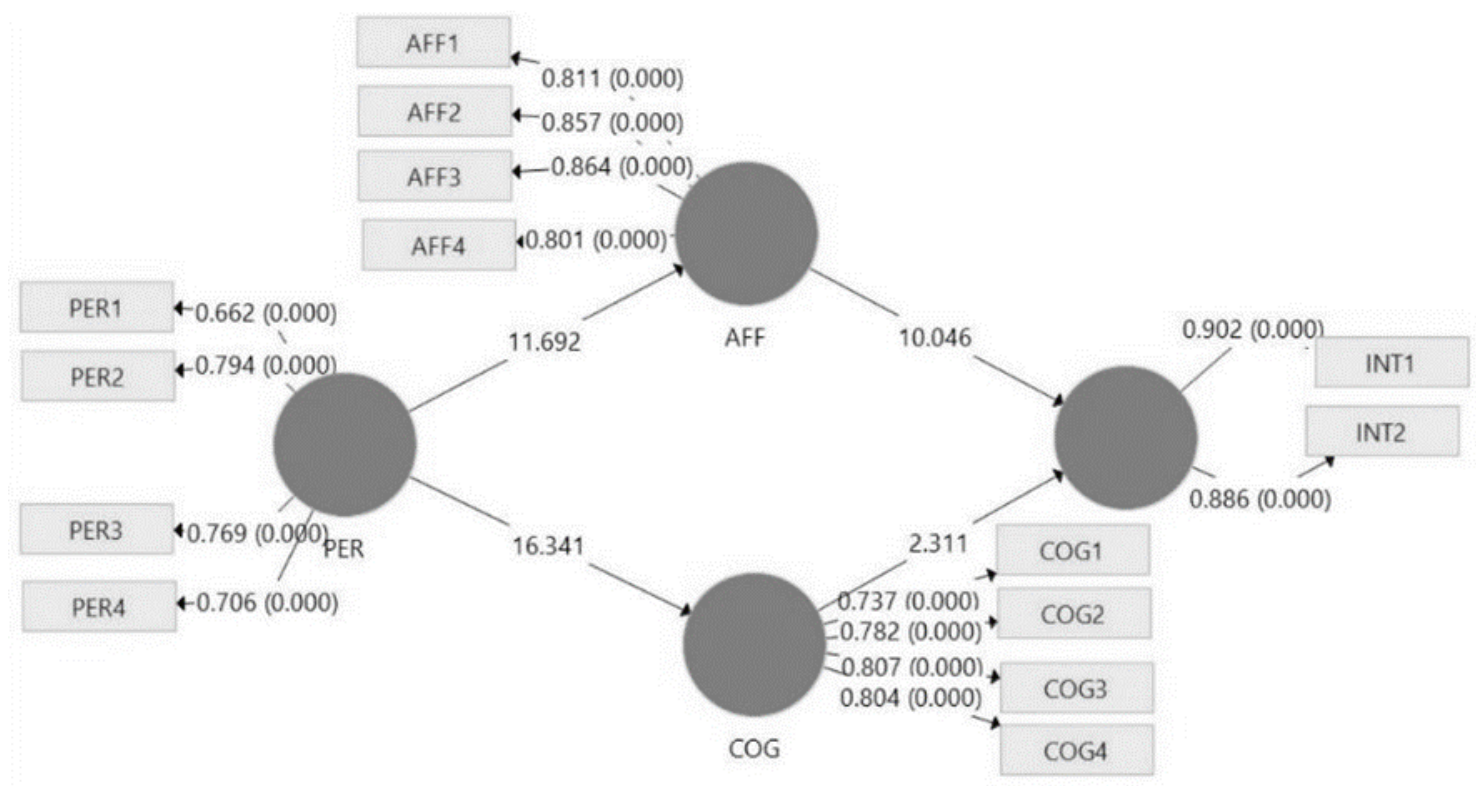

Fig. 1. Research model

Furthermore, this study also found that the affective and cognitive image of tourist destination influence the intention of visiting such kind of tourist destination. It is supported by Chu \& Luckanavanich (2018) that said cognitive and affective image affect the intention to visit. Individuals have a certain image of a tourist destination that drives them to visit it. The result of this study also indicates that individuals believe that social media provides reliable and credible information due to the nature of social media itself. It is considered to have more credibility than other sources of information in promoting tourism, such as official tourism sites, travel agents or advertisements (Fotis, Buhalis and Rossides, 2012). 


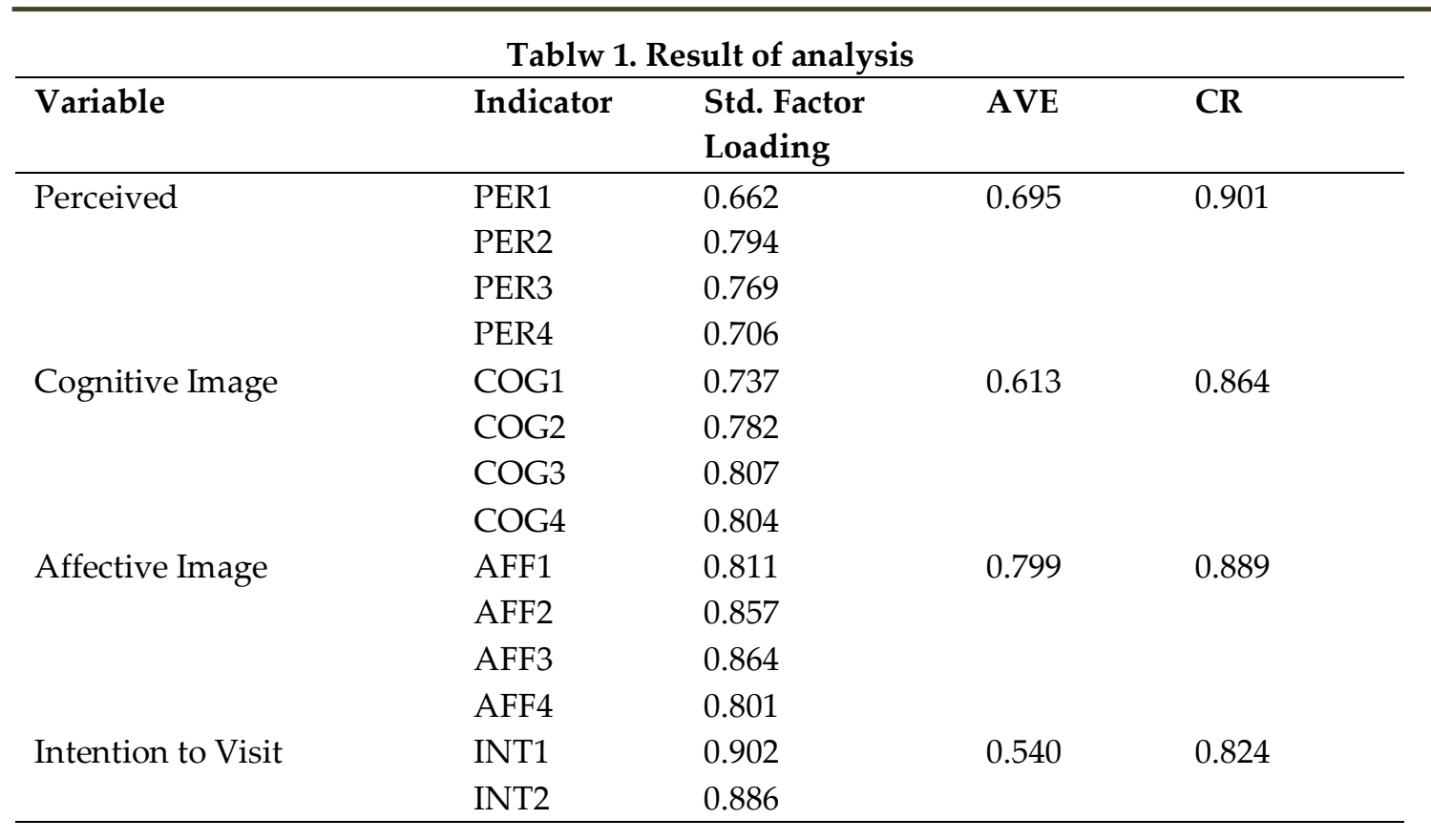

It is in contrast to several cognate studies that show an increase in the interest rates will reduce share prices. Increasing the interest rate will reduce the present value and dividend income in the future; this condition will make the investors carry out diversification of assets (Karini, 2009). Furthermore, an interest rate that is too high will affect the value of the company's cash flow and it can even be a barrier to growth. This condition make companies to bear higher capital costs (Wismantara, 2017). On the other hand, the interest rates that are too high will also reduce purchasing power. If the company is vulnerable to the interest rates, the company's performance will undoubtedly decrease and the share price will continue to be corrected consequently.

\section{Conclusions}

In general, it can be concluded that perceptions can be turned up when individual uses social media affect the tourism industry. This industry needs to understand that social media has a very significant influence on whether or not individual will visit a tourism destination. The results of this study indicate that perceptions arising from social media affect the image of the tourism destination, both in the context of affective and cognitive image. In addition, affective image in the term of pleasure and cognitive image in the term of benefit affect the intention to visit the tourism destination. From the results of the study, it is also found affective image has higher influence than cognitive image.

\section{References}

Badan Pusat Statistik. 2018. Kota Batu dalam Angka 2018. Retrieved from https://batukota.bps.go.id on 2 Februari 2019.

Boston Consulting Group. 2014. Travel goes mobile. [online] Boston: Boston Consulting Group. $\quad$ Retrieved from http://imgstg.bcg.com/Travel_Goes_Mobile_Jun_2014_tcm9-84752.pdf, on January, 2019. 
Chu, C., \& Luckanavanich, S. (2018). The Influence of Social Media Use and Travel Motivation on The Perceived Destination Image and Travel Intention to Taiwan of The Thai People. International Journal of Arts and Commerce, 7(3), 22-36.

Cianga, N., \& Popescu, A. C. (2013). Green Spaces and Urban Tourism Development In Craoiva Municipality in Romania. European Journal of Geography, 4(2), 34-45. Retrieved from http://geografie.ubbcluj.ro/,cianga@geografie.ubbcluj.rohttp://geografie.ubbcluj.ro/ ,http://set.univ-pau.fr/live/

Cooper, Donald R \& Schindler, Pamela S. (2014). Business Research Method, 12th edition. McGraw Hill, New York.

DeVito, J. A. 2011. Komunikasi antar manusia, 5th edition. Karisma Publishing, Tangerang.

eMarketer. 2011. Product recommendations remain low on social networks: Oldfashioned conversation still fosters the most word-of-mouth. Retrieved from http://www.emarketer.com/Article/Product-Recommendations-Remain-LowonSocial-Networks/1008303, on January 6, 2019.

Firzriyani, R. 2018. Ruang Terbuka Hijau di Kota Malang Terus Berkurang. Retrieved from https://nasional.republika.co.id/berita/nasional/daerah/18/03/12/p5h5io423ruang-terbuka-hijau-di-kota-malang-terus-berkurang on January 6, 2019.

Fotis, J., Buhalis, D., \& Rossides, N. (2012). Social media use and impact during the holiday travel planning process, pp. 13-24. Springer-Verlag.

Hair, Joseph F., Black, Wiliam C., Babin, Barry J., \& Anderson, Rolph e. (2014). Multivariate Data Analysis, 7th edition. Pearson Education Limited, Essex.

Hornberger, K. \& Nevill, H. 2011. Should we be promoting tourism sector investment?. Retrieved from https://blogs.worldbank.org/psd/should-we-be-promotingtourism-sector-investment on Januari 10, 2019.

Lestari, S. (2014). Pengembangan Ruang Terbuka Hijau dalam Upaya Mewujudkan Sustainable City (Studi pada Masterplan Pengembangan RTH Tahun 2012-2032). Jurnal Administrasi Publik, 2(3), 381-387. Retrieved from http://administrasipublik.studentjournal.ub.ac.id/index.php/jap/article/view/394

Palacios-Marqués, D., Merigó, J. M., \& Soto-Acosta, P. (2015). Online social networks as an enabler of innovation in organizations. Management Decision, 53(9), 1906-1920. https://doi.org/10.1108/MD-06-2014-0406

Volo, S. (2010). Bloggers' reported tourist experiences: Their utility as a tourism data source and their effect on prospective tourists. Journal of Vacation Marketing, 16(4), 297-311. https://doi.org/10.1177/1356766710380884

Xiang, Z., \& Gretzel, U. (2010). Role of social media in online travel information search. Tourism Management, 31(2), 179-188. https://doi.org/10.1016/j.tourman.2009.02.016

World Economic Forum. 2015. The Travel \& Tourism Competitiveness Report 2015 Growth through Shocks. Retrieved from http://www3.weforum.org/docs/TT15/WEF_Global_Travel\&Tourism_Report_201 5.pdf, on January 6, 2019. 